\title{
Caracterización del hormigón elaborado con áridos reciclados producto de la demolición de estructuras de hormigón
}

\section{Characterization of concrete made with recycled aggregate from concrete demolition waste}

\author{
J. C. Rolón Aguilar ${ }^{(*)}$, D. Nieves Mendoza(*), R. Huete Fuertes(**), B. Blandón González(**), \\ A. Terán Gilmore ${ }^{(* * *)}$ y R. Pichardo Ramírez ${ }^{*}$
}

Recepción/Received: 11-X-05

Aceptación/Accepted: 24-IV-07

RESUMEN

El presente estudio nos permite caracterizar las propiedades físicas, químicas y mecánicas de los áridos reciclados, producto de residuos de la construcción y demolición de estructuras de hormigón, tratándolos antes y después de triturar; caracterizar el hormigón elaborado con áridos reciclados, en su estado fresco y endurecido, diseñando diferentes dosificaciones variando la relación agua/cemento, la cantidad de cemento y el uso de aditivos superplastificantes para disminuir el efecto de la absorción; caracterización que nos permite tener una mayor perspectiva sobre el uso de áridos reciclados en la elaboración de nuevos hormigones.

Palabras clave: caracterización, árido, hormigón, absorción, propiedades mecánicas.
SUMMARY

The present study aimed: to characterize the physical, chemical and mechanical properties of recycled aggregate from construction and concrete structure demolition waste, processed before and after crushing; to characterize fresh and hardened concrete made with such recycled aggregate; and to design different doses varying the water/cement ratio, the amount of cement and the use of superplasticizing admixtures to offset the effects of absorption. The ultimate objective was to provide a broader perspective of the use of recycled aggregate in the manufacture of new concrete.

Keywords: characterization, aggregate, concrete, absorption, mechanical properties.

\section{INTRODUCCIÓN}

La protección del medio ambiente, cuidando la conservación de recursos naturales, así como la disposición final de los residuos de construcción y demolición (RC\&D) de estructuras de hormigón, hacen más factible la práctica del reciclaje, si a esto le agregamos el ahorro del consumo energético que se pueda generar al optimizar

\section{INTRODUCTION}

The demands for environmental protection, in terms of both the conservation of natural resources and the final disposal of construction and demolition waste $(C \& D W)$, make recycling more feasible. Given, moreover, the energy savings inherent in optimizing the shipment of natural aggregate to user sites, economic

\footnotetext{
(*) Universidad Autónoma de Tamaulipas, Tampico (Tamaulipas, México).

(**) Universidad de Sevilla, Sevilla (Sevilla, España).

(***) Universidad Autónoma Metropolitana, Atzcapotzalco (Atzcapotzalco, México). 
el transporte de áridos naturales hacia los centros consumidores, el atractivo económico será un aliciente más para el reciclado de residuos de hormigón.

La evaluación de los áridos, desde un enfoque de desarrollo sostenible, requiere considerar aspectos socioeconómicos y medioambientales, considerando su ciclo de vida que contempla: su extracción, producción, distribución y utilización, no perdiendo de vista el consumo de energía, los contaminantes que produce ${ }^{1}$, lo cual nos permite comparar diversas estrategias y cuantificar los impactos negativos y sus beneficios, de tal forma que nos permita definir el proceso más sostenible para el desarrollo, utilización y reutilización de estos recursos.

La presente investigación parte de la premisa de disminuir la cantidad final de RC\&D de obras de hormigón, que son depositadas en los vertederos clandestinos ${ }^{2}$, preservando con ello al medio ambiente y al paisaje que nos rodea, mediante técnicas de reciclado, reutilizándolos en hormigones nuevos, analizando su posible aplicación estructural, por lo que se estudia el comportamiento de las propiedades mecánicas que inciden en su comportamiento a corto, mediano y largo plazo, tales como la retracción y la fluencia, las cuales muestran algunas diferencias respecto a los hormigones usuales.

\section{ANTECEDENTES}

La recomendación RILEM (1) trata sobre áridos gruesos reciclados de $4 \mathrm{~mm}$ para hormigón. Las especificaciones se basan en la suposición de que la fracción fina $(<4$ $\mathrm{mm}$ ) del hormigón está compuesta de materiales a los que se pueden aplicar las especificaciones tradicionales para este material. RILEM (1) Estas especificaciones establecen diferentes categorías para los áridos gruesos reciclados, e indican el campo de aplicación para el hormigón que contiene tales clases de áridos reciclados. Clasificando como áridos Tipo II a aquellos que se originan en principio en los escombros de hormigón.

P. Kumar et al. (2) definen la importancia que está adquiriendo el rehuso del desecho de hormigón por la industria de la construcción, considerando que el uso final del árido recuperado del desecho de hormigón depende de su limpieza y sanidad, las cuales se controlan por la fuente de origen de los escombros y la tecnología del procesamiento.

Asimismo, el Grupo Español del Hormigón (3) trata de sensibilizar a los distintos técnicos que tienen el poder factors constitute yet another incentive for recycling concrete waste.

From the perspective of sustainable development, both socio-economic and environmental aspects must be taken into account when evaluating aggregate and its life cycle, including: extraction, production, distribution and use, along with the energy consumed and pollutants ${ }^{1}$ generated. All this provides grounds for comparing different strategies and quantifying their adverse and beneficial impact to define the most sustainable processes for the development, use and re-use of these resources.

The premise underlying the present research is that the final amount of C\&DW in concrete works, which is deposited in illegal dumps ${ }^{2}$, needs to be reduced to conserve the environment and the surrounding landscape through recycling, re-using this waste in new concrete and analyzing its possible structural applications. This entails studying the mechanical properties affecting its short-, medium- and long-term behaviour, such as shrinkage and creep, which differ with respect to normal concrete.

\section{BACKGROUND}

The 1998 RILEM recommendation (1) on $4 \mathrm{~mm}$ coarse recycled aggregate for concrete assumes that the fines ( $<4 \mathrm{~mm}$ ) to be used comprise materials meeting conventional specifications. The standard establishes different categories for coarse recycled aggregate and lists the possible uses for concrete made with this material. Aggregate primarily drawn from concrete rubble is classified as Type II aggregate in the recommendation.

P. Kumar et al. (2) define the importance that concrete reuse is acquiring in the construction industry, noting that the final utility of aggregate reclaimed from concrete waste depends on its general condition, cleanliness and so on, which aspects are in turn contingent upon the origin of the rubble and the processing technology used.

At the same time, the Grupo Español del Hormigón (3) attempts to sensitize engineers and architects vested

1. Tales como ruido, polvo, calidad del aire, calidad del agua, paisaje, etc. / Such as noise, dust, air and water pollution, landscape impact, and so on.

2. No existen vertederos de RC\&D municipales controlados ni regidos por la ley en México. / There are no municipal C\&DW dumping sites or any federal legislation governing such sites in Mexico. 
de decisión en la planificación, proyecto, construcción, fabricación de materiales y explotación, así como a los usuarios, de que la construcción y la desconstrucción son complementarias y forman parte de un conjunto, el cual debe ser muy sensible con el medio ambiente, y éste siempre debe estar presente desde el primer momento de la planificación y concepción de una estructura.

"La reducción del consumo de energía y la reducción de materiales de desecho son elementos fundamentales para la protección del medio ambiente, dando lugar al Desarrollo Sostenible."

Proponen una metodología para la producción y el uso del árido reciclado, basados en el documento RILEM TC 121 (4), recogiendo una serie de propiedades que deben tenerse en cuenta en los materiales reciclados para su uso en hormigón.

Huete F. et al. (5), hacen un análisis sobre los residuos generados por el hombre en su actividad cotidiana, en donde el sector de la construcción, uno de los principales sectores de la economía, interpreta su papel protagonista a la hora de generar residuos, donde el problema que origina es el gran volumen que se genera, superando incluso a los domésticos, lo que provoca un gran impacto sobre el medio ambiente. Recomiendan diseñar el proyecto de construcción de tal forma que reutilice sus residuos, reduciendo con ello la cantidad de Residuos de Construcción y Demolición (RC\&D) a verter.

Natalini et al. (6) concluyen que la reutilización de los RC\&D lleva a una economía en los gastos de la construcción eliminando los gastos de transporte, lo cual representa un ahorro de materiales y recursos naturales recomendando la adopción de los RC\&D, a fin de obtener estadísticas confiables y comparables a nivel nacional e internacional.

Parra et al. (7) describen el modo de elaborar un hormigón a escala industrial, con áridos reciclados y verificar el comportamiento y prestaciones de dicho hormigón tanto inicialmente como con el tiempo, mediante la construcción de diversas estructuras. En su dosificación, incluyen el 52\% de árido natural, el $41 \%$ de hormigón y el $7 \%$ de cerámica (ladrillo). En su trabajo concluyen que los ensayos realizados a los áridos fueron adecuados para su utilización en el objeto del proyecto, ya que se asemejan los resultados a los de un árido convencional en todos los ensayos de la EHE; recomiendan determinar el comportamiento de probetas frente al ataque con agua de mar y con aguas puras, someter a las probetas a ciclos de hielo-deshielo y determinar en todas ellas las variaciones de dimensiones y el comportamiento del árido.

De igual forma, Gómez et al. (8) analizan un hormigón reciclado con sustitución parcial de áridos naturales por los áridos reciclados de hormigón. La materia prima del with decision-making powers in planning, design, construction, material manufacture and use, as well as users, to the idea that construction and de-construction are complementary and form a part of a whole. The group maintains that concern for the environment should be built into projects from the very earliest stages of structural planning and design.

"The reduction of energy consumption and waste materials is one of the cornerstones of environmental protection and Sustainable Development."

It likewise proposes a methodology for producing and using recycled aggregate based on RILEM TC 121 (4), which determines the properties to be borne in mind when using recycled materials in concrete manufacture.

In an analysis of everyday man-made waste, Huete et al. (5) note that construction, one of the major industries of any economy, plays a lead role in generating refuse. The problem is that the huge volumes involved, which exceed the volume of domestic waste, have a highly adverse impact on the environment. These authors urge designers to reuse the industry's own waste to reduce the amount of C\&DW that needs to be discarded.

Natalini et al. (6) conclude that C\&DW reuse leads to lower construction costs by ruling out the need for shipping, with the respective savings in materials and natural resources. They recommend the adoption of C\&DW recycling standards to obtain reliable and nationally and internationally comparable statistics.

Parra et al. (7) describe ways to manufacture industrialscale concrete with recycled aggregate and verify both the initial and long-term performance of such concrete by building several structures. They used a dosage consisting in 52\% natural, $41 \%$ concrete and $7 \%$ clay-based (brick) aggregate. They concluded that the above aggregate was suitable for use in the structure studied, inasmuch as the results obtained when tested to Spanish concrete code requirements were similar to the findings for conventional aggregate. Their recommendations include determining specimen behaviour when exposed to seawater and fresh water; subjecting specimens to freeze-thaw cycles and determining dimensional variations and aggregate behaviour.

Similarly, Gómez et al. (8) analyzed recycled concrete in which natural aggregate was partially replaced by recycled concrete aggregate. The raw material for the 
árido reciclado la obtienen de la elaboración de probetas y del triturado de las mismas con un envejecimiento de 150 días. La sustitución de áridos naturales por áridos reciclados se realizó con iguales volúmenes de los porcentajes de peso a sustituir.

Concluyen que los áridos reciclados procedentes de hormigón presentan un elevado nivel de poros, con posibilidad de absorber más agua y una densidad más baja que los áridos de uso acostumbrado. Los resultados de las propiedades mecánicas estáticas de hormigones apuntan a una reducción en sus cuantías, dichas reducciones son proporcionales y producidas por el incremento de reemplazo de áridos naturales por áridos reciclados procedentes de hormigón y que las variaciones que se puedan presentar entre las propiedades de los diferentes áridos reciclados de hormigón son una función del tipo de hormigón original, de su estado de conservación y, por último, del proceso de producción del cual son creados.

Todos estos trabajos van dirigidos a actuar de forma óptima en lo económico y de manera razonable con el medio ambiente, tratando de tener en la construcción un ciclo de vida lo más cerrado posible.

\section{PROCEDIMIENTO EXPERIMENTAL}

Se ha desarrollado un plan de trabajo que podemos clasificar en tres etapas (Figura 1), la primera que consiste en identificar y obtener la materia prima, la cual será procedente de la demolición de pavimentos, cuidando de que no esté contaminada con acero. La segunda, donde se procesa esta materia prima, obteniendo así el árido grueso que se utilizará en la elaboración del hormigón, caracterizando a ésta física y químicamente; y una tercera que consistirá en diseñar mezclas de hormigón para posteriormente caracterizarlo en su estado fresco y endurecido.

Se generará una matriz de variantes para la elaboración de las mezclas, la cual nos va a permitir definir claramente el comportamiento del hormigón en su estado fresco y endurecido, caracterizando de esta forma los resultados obtenidos en las pruebas de laboratorio del hormigón reciclado.

\section{RESULTADOS}

Las características del árido que se puede obtener y la homogeneidad de sus propiedades dependen directamente de las correspondientes características del hormigón original, por lo que la historia, características y composición son de gran relevancia para evaluar el posible reciclado del material de demolición. Es por ello que la selección en origen es decisiva, y es de gran relevancia tener bien definidas las características del hormigón original. recycled aggregate was obtained from 150-day specimens specifically manufactured for this purpose. Natural aggregate was replaced by equal volumes of the percentage by weight to be replaced.

These authors concluded that recycled aggregate made from concrete is characterized by greater porosity and therefore water absorption, as well as by lower density than natural aggregate. The results of static mechanical concrete testing indicated lower performance. These reductions were proportional to and occasioned by the replacement of natural aggregate by recycled concrete aggregate. They also observed that the variations between the different types of recycled concrete aggregate depend on the type and condition of the original concrete as well as the processing technique used to produce it.

All these papers pursue economic optimization and the attainment of reasonable environmental results, in an attempt to close construction life cycles as far as possible.

\section{EXPERIMENTAL PROCEDURE}

The work plan designed was divided into three stages (Figure 1). The first consisted in identifying and obtaining prime materials, which were taken from pavement demolition works, ensuring that the waste contained absolutely no steel. In the second or processing stage, coarse aggregate was obtained for subsequent use in concrete manufacture. This stage also included the physical and chemical characterization of the concrete product. The third consisted in designing concrete mixes for subsequent characterization of the fresh and hardened material.

A matrix of variables was generated to formulate the mixes, from which the behaviour of fresh and hardened concrete could be clearly defined on the grounds of laboratory tests conducted on recycled concrete specimens.

\section{RESULTS}

The characteristics of the resulting aggregate and the uniformity of its properties depend directly on the characteristics of the original concrete. For this reason, the history, characteristics and composition are key considerations when evaluating demolition materials for possible recycling. Selection at the source is therefore decisive and the accurate definition of the characteristics of the original concrete is crucial. 


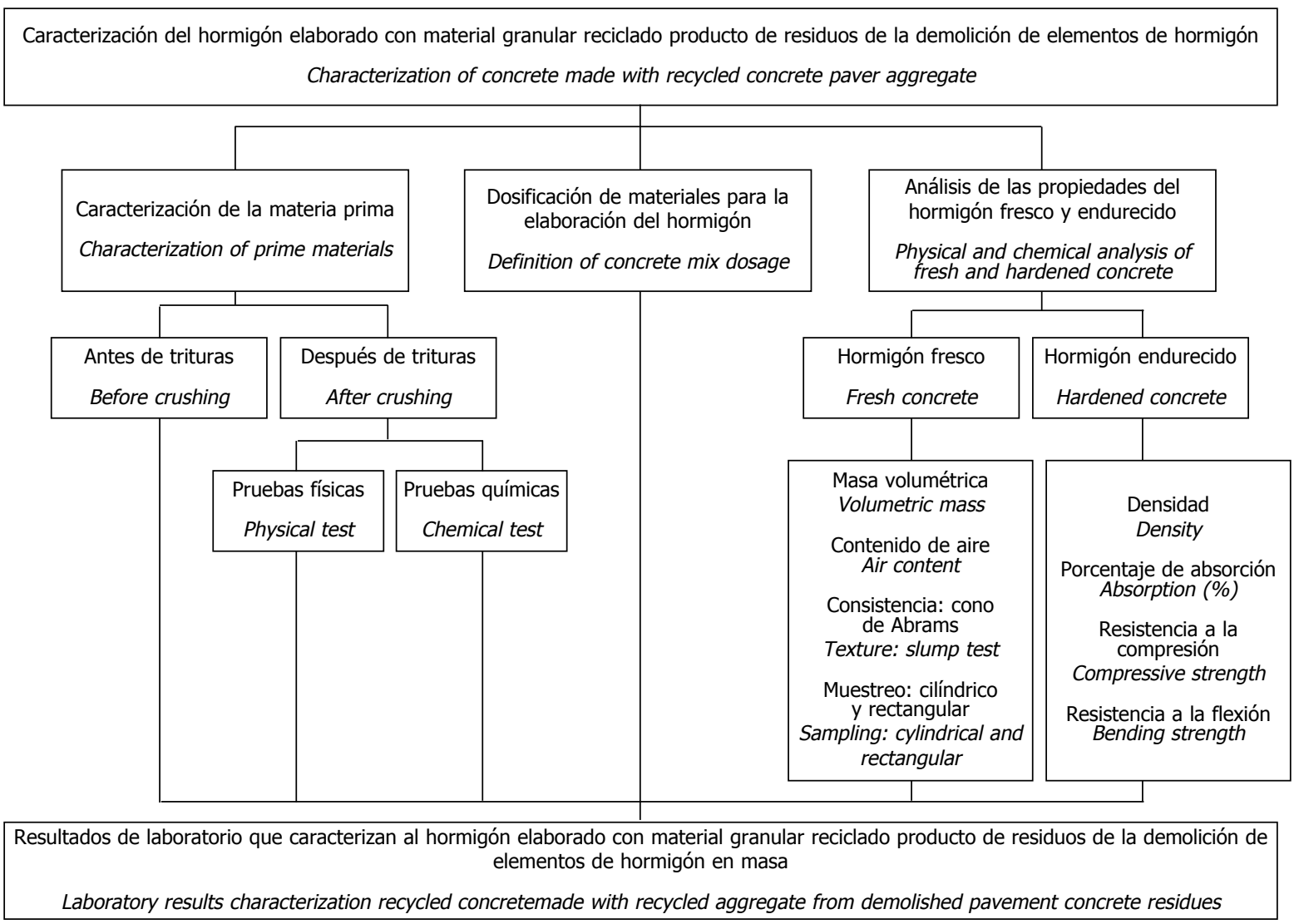

Figura 1. Esquema jerarquizado de objetivos de investigación.

Figure 1. Chart of hierarchized research objectives.

Esta primera caracterización de probetas de hormigón consistirá básicamente en tres actuaciones: a) La edad de servicio del mismo; b) Determinar la capacidad de carga después de haber sido demolidos los pavimentos; y c) Identificar la procedencia de los áridos gruesos con que fueron elaborados, para conocer su naturaleza mineralógica3.

Dado que en México no existen vertederos controlados de residuos de construcción, y eso nos representa la variante de no tener determinada la procedencia de los mismos, se decidió tomar las muestras directamente de las obras de demolición de pavimentos. Esta selección se basó en identificar pavimentos de hormigón que cumplieran con los parámetros de las variantes a analizar, es decir, que el hormigón estuviera constituido por áridos de las dos canteras que existen en la localidad, así como conocer el tiempo de servicio.

Fue de esta manera como se detectaron cuatro obras de demolición de pavimentos de hormigón, de las cuales se obtuvieron las placas de hormigón resumiendo los resultados en la Tabla 1.
This initial characterization of concrete specimens consists essentially in determining: a) service life; b) bearing capacity after the pavements are demolished; and c) origin of the coarse aggregate with which it was made, to ascertain its mineralogy3.

Inasmuch as the absence of controlled dumping grounds for construction waste in Mexico precludes any possibility of determining the origin of such refuse, the samples for this study were taken directly from pavement demolition works. This entailed identifying concrete pavements that met the requirements defined for the variables to be analyzed, i.e., the concrete had to be made with aggregate from two local quarries, and its actual service life had to be known.

Finally, concrete pavers were obtained from four demolition sites meeting those requirements. The results are summarized in Table 1.

3. Proceden de dos canteras de materiales, uno, de roca triturada procedente de rocas sedimentarias con abundante carbonato de calcio y otro, de río, árido de canto rodado, siendo Caliza tipo mudstone y greinstone. / They were supplied by two quarries, one that crushes sedimentary rock with a high calcium carbonate content, and the other that supplies mudstone and greenstone type river gravel. 
El tratamiento de los residuos de la demolición de estructuras de hormigón consistió en tres pasos: a) Prelavado para eliminar contaminantes como arcillas, limos o material orgánico (Figura 2); b) Triturado (Figura 3); y c) Lavado posterior para eliminar el material fino que se produce en la trituración producto del cementante (Figura 4).

Para el proceso de lavado anterior y posterior al triturado, se utilizó una hidrolavadora con presión de 10 atmósferas, asimismo, se habilitó un triturador a escala para poder triturar en el laboratorio las probetas obtenidas, que consiste en una muela metálica mecánica, la cual es movida por un motor de $5 \mathrm{HP}$, teniendo la limitante, que el material de entrada no debe exceder de 4" de espesor.

Una vez lavadas las probetas de hormigón seleccionadas, y dado que la mayoría de éstas eran de tamaños mínimos de $15^{\prime \prime}$ de ancho, se procedió primeramente a fracturarlas a tamaños más pequeños a través de golpes con mazos de $10 \mathrm{lb}$. de peso, hasta obtener un tamaño máximo de 4", que es el requerido por el triturador del laboratorio. Teniendo ya el material cribado y seleccionado, se procedió a triturar para obtener gravas de tamaño máximo de $1^{\prime \prime}$, el cual, posteriormente, se fue cribando manualmente y se desechaba el material que sobrepasaba el tamaño de una pulgada. Todo el material que cumplía con el tamaño máximo nominal se procedió a lavarlo nuevamente a través de una malla de $2 \mathrm{~mm}$ de luz, para eliminar todo el material fino procedente del cementante anterior suelto y adherido al árido, dado que se parte de la premisa de que el material cementante adherido al árido grueso reciclado es un material perjudicial al mismo, ya que eso incrementa su porcentaje de absorción, lo que genera un consumo mayor de agua proyectado en el diseño de la mezcla de hormigón, así como una falla en la adherencia del nuevo árido con los materiales que componen la mezcla del hormigón. Después de verificar que no estuvieran contaminados de finos, se dispone a su almacenaje, para proceder con ellos a la caracterización física y química de los áridos triturados.
The concrete waste was processed as follows: a) prehosing to eliminate pollutants such as clay, lime or organic material (Figure 2); b) crushing (Figure 3); and c) post-hosing to eliminate any cementitious fines generated during the crushing process (Figure 4).

Pre- and post-hosing was carried out with a 10-atmosphere hydrowash. A laboratory scale crusher was also built. With a steel grinding wheel driven by a 5 HP engine, it was able to process input material up to 4 " thick.

Since most of the concrete specimens selected were at least 15" wide, after hosing they were hammered into fragments no larger than the 4" for feeding into the laboratory crusher. After sieving, the material was crushed to obtain gravel measuring no more than $1^{\prime \prime}$ and then manually re-sieved, separating out any material retained. All the crushed concrete meeting the maximum nominal size requirement was placed inside a 2-mm mesh net for re-hosing to remove all the cementitious fines adhering to the aggregate. This was a necessary precaution, for the high absorption potential of such fines increases water consumption and weakens bonding between the new aggregate and the other materials comprising the concrete mix. After hosing, the aggregate was inspected to ensure that it was free of all fines and stored for subsequent physical and chemical characterization.

Tabla 1 / Table 1

Caracterización de las probetas de residuos de la demolición de pavimentos de hormigón Characterization of paver demolition waste

\begin{tabular}{|c|c|c|c|c|}
\hline $\begin{array}{c}\text { No. de Muestra } \\
\text { Sample Number } \\
\text { RDPH }\end{array}$ & $\begin{array}{c}\text { Edad (años) } \\
\text { Age (years) }\end{array}$ & $\begin{array}{c}\text { Resistencia a la } \\
\text { Compresión Inicial } \\
\text { Initial compressive } \\
\text { strength } \\
\text { MPa }\end{array}$ & $\begin{array}{c}\text { Naturaleza } \\
\text { Mineralógica } \\
\text { Mineral origin } \\
\text { Mass } \\
\text { (kg) }\end{array}$ \\
\hline 1 & 15 & 28.0 & I & II \\
\hline 2 & 12 & 23.8 & II & II \\
\hline 3 & 12 & 20.4 & 567.5 \\
\hline
\end{tabular}




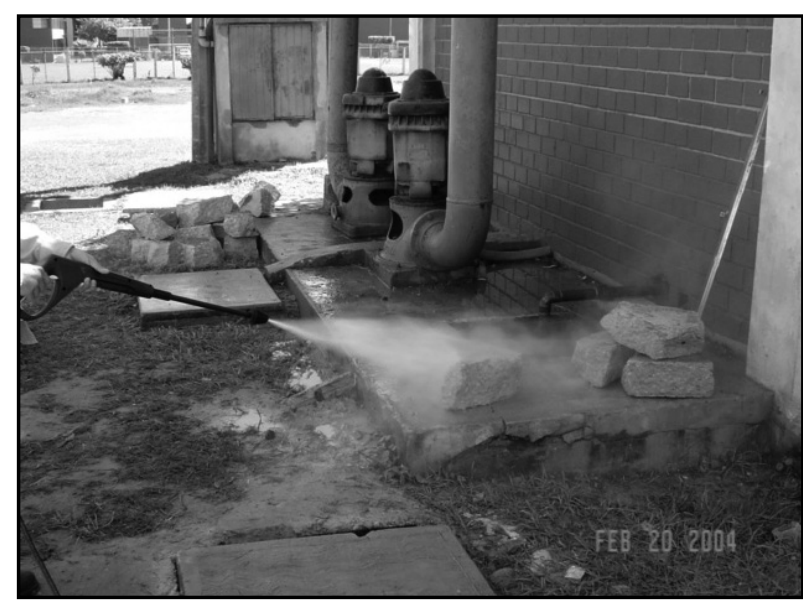

Figura 2. Lavado a presión de las probetas de hormigón para eliminar contaminantes.

Figure 2. Pre-crushing pressure hosing of concrete specimens.

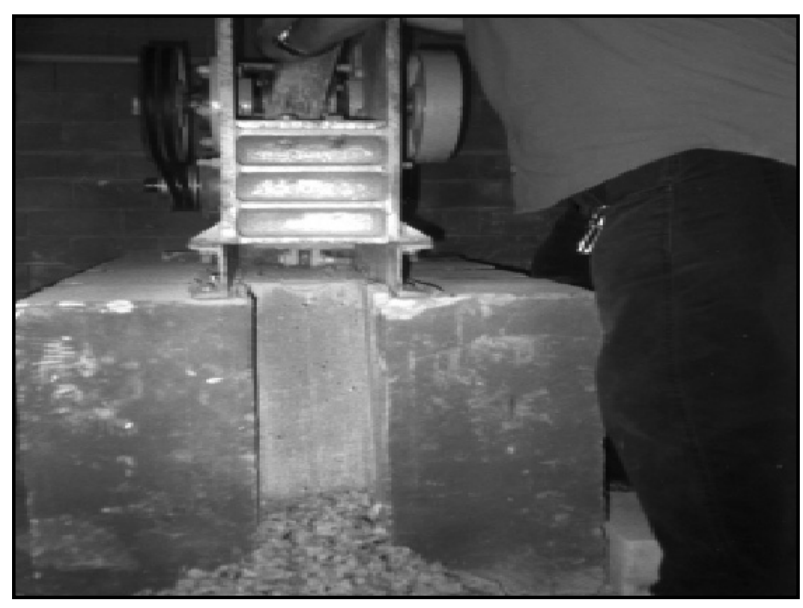

Figura 3. Triturado de probetas de hormigón para obtener los áridos.

Figure 3. Paver crushing to produce aggregate.

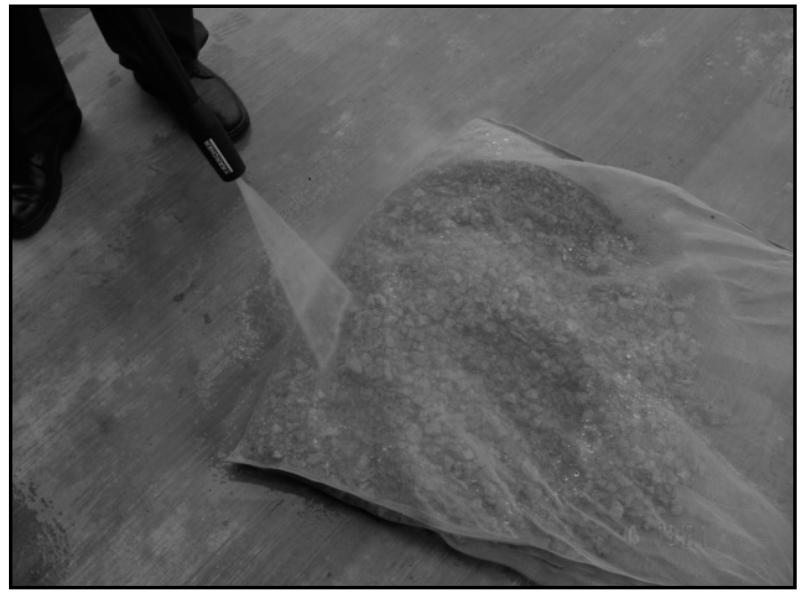

Figura 4. Lavado posterior al triturado para eliminar material fino.

Figure 4. Post-crushing pressure hosing of aggregate to remove fines.

El documento RILEM TC 121 (4) menciona una serie de propiedades que se debe tener en cuenta en los materiales reciclados para su uso en hormigón, y ante la ausencia de normativas obligatorias para el cumplimiento de estos materiales, se tomaron como una guía estas recomendaciones, basándonos en los procedimientos tradicionales de las pruebas que se realizan en áridos vírgenes. La Normativa que se utilizó fueron las Normas Españolas UNE (9), con lo cual se obtuvo la caracterización del material granular reciclado, evaluando así la granulometría de las partículas (Tabla 2), con lo cual podemos resumir que cumple con las normas que rigen a los áridos gruesos para la elaboración de hormigón.

Los resultados obtenidos en las pruebas físicas y químicas realizadas a los áridos reciclados (Tabla 3) nos determinan unos parámetros importantes a evaluar, dado que se lavó
RILEM TC 121 (4) lists a series of properties that should be borne in mind when using recycled materials in concrete. In the absence of statutory standards defining the requirements to be met by these materials, these recommendations were taken as a guide. The tests conducted were the trials conventionally applied to natural aggregate, pursuant to Spanish UNE Standards (9). The recycled granular material was characterized and its particle size distribution determined (Table 2). The results showed that it met the general requirements governing coarse aggregate for concrete manufacture.

The results obtained in the physical and chemical tests conducted on recycled aggregate (Table 3 ) identified the parameters that had to be evaluated. Inasmuch as the 
este material después de haber triturado las muestras obtenidas, hubo tres resultados nulos (N.A.), ya que la parte fina no existía prácticamente, cumplió satisfactoriamente 5 de las pruebas, pero, sin embargo, se confirmó la problemática en la absorción y el contenido de partículas blandas, recordando que para ambos casos es debido al material cementante adherido al árido.

Las proporciones para elaborar la mezcla fueron en base al método ASTM-C (10) 143 y 192 contemplado para materiales que cumplen todos los requisitos de calidad, considerando que para áridos reciclados no existen normas en diseño de mezclas. Tomando en consideración las variantes a analizar, tales como: la cantidad de cemento, la relación agua/cemento y el uso de aditivo material was hosed after crushing the samples, three nil (N.A.) results were obtained, for there were essentially no fines. Satisfactory results were obtained in five of the tests, although difficulties were encountered in connection with absorption and soft particle content, both of which can be attributed to the cementitious material adhering to the aggregate.

The proportions used in the mixes were based on ASTMC (10) methods 143 and 192 for materials meeting all quality standards, given that there are no standards for mix design for recycled aggregate. In light of the variables to be analyzed, which included amount of cement, water/cement ratio and use of superplasticizing admixture (Table 4), eight different mixes were prepared, from

Tabla 2 / Table 2

Granulometría del material granular reciclado Particle size distribution in the recycled aggregate

\begin{tabular}{|c|c|c|c|c|c|}
\hline Tamiz & $\begin{array}{c}\text { Requerimiento } \\
\text { que debe pasar } \\
\text { en \% de peso } \\
\text { Per cent by } \\
\text { mass that } \\
\text { must pass }\end{array}$ & $\begin{array}{c}\text { Material } \\
\text { retenido } \\
\text { Amount } \\
\text { retained } \\
\mathbf{( g )}\end{array}$ & $\begin{array}{c}\text { Retenido } \\
\text { Amount } \\
\text { retained } \\
\mathbf{( \% )}\end{array}$ & $\begin{array}{c}\text { Pasa } \\
\text { Passing } \\
\mathbf{( \% )}\end{array}$ & $\begin{array}{c}\text { Cumple } \\
\text { Conforming }\end{array}$ \\
\hline $\begin{array}{c}25.00 \\
\mathrm{~mm}\end{array}$ & 100 & 0 & 0 & 100 & Sí / Yes \\
\hline $\begin{array}{c}19.00 \\
\mathrm{~mm}\end{array}$ & $90-100$ & 120 & 6 & 94 & Sí / Yes \\
\hline $\begin{array}{c}12.50 \\
\mathrm{~mm}\end{array}$ & $20-55$ & 1,150 & 57.5 & 36.5 & Sí / Yes \\
\hline $\begin{array}{c}9.50 \\
\mathrm{~mm}\end{array}$ & 0 a-15 & 490 & 24.5 & 12 & Sí / Yes \\
\hline $\begin{array}{c}4.74 \\
\mathrm{~mm}\end{array}$ & 0 a-15 & 180 & 9 & 3 & Sí / Yes \\
\hline
\end{tabular}

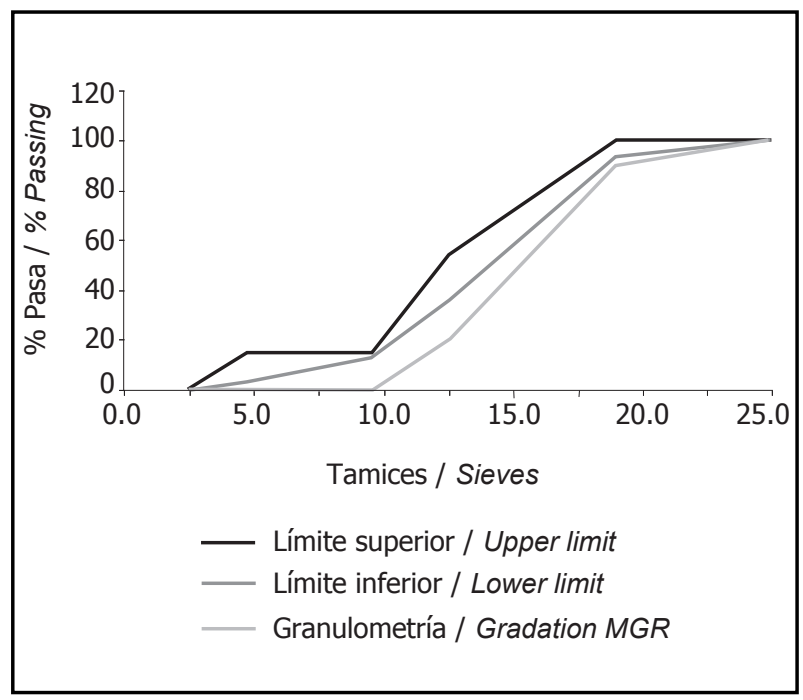

Tabla 3 / Table 3

Resultados de las pruebas físicas y químicas realizadas a los áridos reciclados Results of physical and chemical testing of recycled aggregate

\begin{tabular}{|c|c|c|c|}
\hline \multicolumn{4}{|c|}{$\begin{array}{c}\text { Limitaciones y resultados de las pruebas a los áridos reciclados } \\
\text { Required and tested values for recycled aggregates }\end{array}$} \\
\hline Prueba / Test & Limitaciones / Requirement & Resultado / Test value & Cumple / Conforming \\
\hline \% de absorción / Absorption (\%) & $<5 \%$ & $11.16 \%$ & No \\
\hline Coeficiente de forma / Form factor & $>0.20$ & $0.217-0.235 \%$ & Sí Yes \\
\hline Índice de lajas / Scaling & $<30$ & $20.90 \%$ & Sí Yes \\
\hline EA & $>75 \%$ & $79.27 \%$ & N.A. \\
\hline Terrones de arcilla / Clay clods & $0.25 \%$ & $0 \%$ & N.A. \\
\hline Materia orgánica / Organic matter & - & $0 \%$ & No \\
\hline Partículas blandas / Soft particles & $5 \%$ & $64.66 \%$ & N.A. \\
\hline Material de bajo peso específico & $1 \%$ & $0 \%$ & Sí / Yes \\
\hline Material with low specific weight & & & Sí / Yes \\
\hline Contenido de Sulfatos / Sulphate content & $<0.8 \%$ & $0.56 \%$ & $0.04 \%$ \\
\hline Contenido de Cloruros / Chloride content & $<0.05 \%$ & & \\
\hline
\end{tabular}


superfluidificante (Tabla 4), se realizaron 8 mezclas diferentes, obteniendo en cada una de ellas 3 probetas cilíndricas para realizar pruebas de compresión, así como 3 probetas rectangulares para pruebas de flexión, todas ellas para ensayar a la edad de 3, 7, 14 y 28 días, respectivamente. El $100 \%$ del material granular grueso que se utilizó proviene de la trituración de residuos de la demolición de pavimentos de hormigón en masa y tratados tal como se describió anteriormente, asimismo, el material granular fino es producto convencional extraído de la cantera de arena que cumple con las normas ASTM.

Una vez definidas las mezclas de hormigón, se procedió a elaborar cada una de ellas, para lo cual se planteó un esquema de ensayos característicos que nos permitieran al final definir las características de estas mezclas tanto en su estado fresco (Tabla 5) como endurecido (Tabla 6). each of which three cylindrical and three rectangular specimens were made for conducting compression and bending strength tests, respectively, at 3, 7, 14 and 28 days. One hundred per cent of the coarse granular material used consisted in crushed bulk concrete pavement waste processed as described above. The fines were a conventional product taken from an ASTM-compliant sand bank.

The mixes were prepared to the above-mentioned designs and tested in accordance with a scheme formulated to determine fresh (Table 5) and hardened concrete characteristics (Table 6).

Tabla 4 / Table 4

Matriz de análisis comparativo del diseño de mezclas de hormigón elaborado con áridos reciclados modificando la relación a/c, cantidad de cemento y uso de aditivo superfluidificante

Mix design matrix for concrete made with recycled aggregate, varying the $w / c$ ratio, cement content and amount of superplasticizing admixture

\begin{tabular}{|c|c|c|c|c|c|c|}
\hline \multirow[t]{2}{*}{$\begin{array}{l}\text { Amasado } \\
\qquad M i x\end{array}$} & \multicolumn{5}{|c|}{$\begin{array}{c}\text { Dosificación } \\
\text { Dose } \\
\left(\mathbf{k g} / \mathrm{m}^{3}\right) \\
\end{array}$} & \multirow{2}{*}{\begin{tabular}{|c|} 
Aditivo \\
Superplastificante \\
Superplasticizing \\
admixture \\
(I)
\end{tabular}} \\
\hline & $\begin{array}{c}\text { Relación } \\
A / C \\
\text { W/C ratio }\end{array}$ & $\begin{array}{c}\text { Cemento } \\
\text { Cement }\end{array}$ & $\begin{array}{l}\text { Agua } \\
\text { Water }\end{array}$ & $\begin{array}{l}\text { Arena } \\
\text { Sand }\end{array}$ & $\begin{array}{l}\text { Grava } \\
\text { Gravel }\end{array}$ & \\
\hline A 1 & 0.65 & 300 & 195 & 880 & 810 & 0 \\
\hline A 2 & 0.57 & 300 & 172 & 938 & 810 & 0 \\
\hline A 3 & 0.65 & 340 & 221 & 781 & 810 & 0 \\
\hline A 4 & 0.57 & 340 & 195 & 847 & 810 & 0 \\
\hline A 5 & 0.65 & 300 & 195 & 880 & 810 & 1.2 \\
\hline A 6 & 0.57 & 300 & 172 & 938 & 810 & 1.2 \\
\hline A 7 & 0.65 & 340 & 221 & 781 & 810 & 1.4 \\
\hline A 8 & 0.57 & 340 & 195 & 847 & 810 & 1.4 \\
\hline
\end{tabular}

Tabla 5 / Table 5

Resultados de las pruebas físicas realizadas al hormigón en su estado fresco Test results for fresh concrete made with recycled aggregate

\begin{tabular}{|c|c|c|c|}
\hline $\begin{array}{c}\text { Mezcla No. } \\
\text { Mix No. }\end{array}$ & $\begin{array}{c}\text { Masa volumétrica } \\
\text { Volumetric mass } \\
\left(\mathbf{k g} / \mathbf{m}^{\mathbf{3}}\right)\end{array}$ & $\begin{array}{c}\text { Contenido de aire } \\
\text { Air content } \\
\mathbf{( \% )}\end{array}$ & $\begin{array}{c}\text { Asiento } \\
\text { S/ump } \\
\text { (cm) }\end{array}$ \\
\hline 1 & 2183 & 2.8 & 8 \\
\hline 2 & 2216 & 2.4 & 5 \\
\hline 3 & 2150 & 2.5 & 16 \\
\hline 4 & 2187 & 2.5 & 13 \\
\hline 5 & 2184 & 2.2 & 8 \\
\hline 6 & 2218 & 2.4 & 21 \\
\hline 8 & 2149 & 2.2 & 14 \\
\hline
\end{tabular}


El contenido de aire en todas las mezclas resultó estar por encima del $1,5 \%$ esperado según el diseño de la mezcla. De igual forma, el asiento en cono de Abrams cumplió el rango esperado en sus límites inferiores para los cuatro primeros casos, solucionando este problema con el uso del aditivo superplastificante.

Definitivamente, el árido reciclado, producto de la demolición de pavimentos de hormigón, tiene ciertas desventajas físicas y mecánicas con respecto a los áridos naturales, esto debido a que en realidad es un árido compuesto por dos materiales, un árido natural y el mortero adherido, lo que conlleva el tener un nuevo material con características diferentes y desventajas mecánicas, tales como la porosidad, absorción, adherencia a los nuevos elementos que conforman el hormigón, baja densidad y efectos de baja resistencia un tanto aceptable a la compresión.
In all the mixes, the air content was found to be over the $1.5 \%$ design value. Similarly, slump test results, which fell in the lower part of the expected range in the first four cases, were improved with the use of a superplasticizing admixture.

In conclusion, due to its hybrid composition (natural aggregate and the mortar bonded to it), recycled aggregate made from concrete pavers has physical and mechanical shortcomings compared to natural materials. The result is a new material with different characteristics and poorer performance than natural aggregate in terms of porosity, absorption, bonding to new elements in the concrete, low density and compressive strength.

Tabla 6 / Table 6

Resultados de las pruebas realizadas al hormigón endurecido Test results for hardened concrete

\begin{tabular}{|c|c|c|c|c|c|}
\hline \multirow[t]{3}{*}{$\begin{array}{l}\text { Amasado } \\
\text { Mix }\end{array}$} & \multirow{3}{*}{$\begin{array}{l}\text { Hormigón fresco } \\
\text { Fresh concrete } \\
\text { asiento } \\
\text { slump } \\
\text { (cm) }\end{array}$} & \multicolumn{4}{|c|}{$\begin{array}{l}\text { Hormigón endurecido } \\
\text { Hardened concrete }\end{array}$} \\
\hline & & \multirow[t]{2}{*}{$\begin{array}{l}\text { \% de Absorción } \\
\text { Absorption (\%) }\end{array}$} & \multirow[t]{2}{*}{$\begin{array}{l}\text { Edad (días) } \\
\text { Age (days) }\end{array}$} & \multicolumn{2}{|c|}{$\begin{array}{c}\text { Resistencia } \\
\text { Strength } \\
\text { (MPa) }\end{array}$} \\
\hline & & & & $\begin{array}{l}\text { Compresión } \\
\text { Compressive }\end{array}$ & $\begin{array}{c}\text { Flexotracción } \\
\text { Bending }\end{array}$ \\
\hline \multirow{3}{*}{ A 1} & \multirow{3}{*}{8} & \multirow{3}{*}{9.03} & 7 & 13.13 & 1.741 \\
\hline & & & 14 & 15.87 & 2.192 \\
\hline & & & 28 & 19.82 & 2.965 \\
\hline \multirow{3}{*}{ A 2} & \multirow{3}{*}{5} & \multirow{3}{*}{9.28} & 7 & 14.95 & 1.939 \\
\hline & & & 14 & 20.60 & 2.816 \\
\hline & & & 28 & 24.19 & 3.533 \\
\hline \multirow{3}{*}{ A 3} & \multirow{3}{*}{16} & \multirow{3}{*}{8.15} & 7 & 13.21 & 1.737 \\
\hline & & & 14 & 15.96 & 2.211 \\
\hline & & & 28 & 19.91 & 2.960 \\
\hline \multirow{3}{*}{ A 4} & \multirow{3}{*}{9} & \multirow{3}{*}{9.03} & 7 & 14.84 & 1.921 \\
\hline & & & 14 & 20.45 & 2.833 \\
\hline & & & 28 & 24.04 & 3.532 \\
\hline \multirow{3}{*}{ A 5} & \multirow{3}{*}{13} & \multirow{3}{*}{8.52} & 7 & 13.86 & 1.838 \\
\hline & & & 14 & 16.59 & 2.225 \\
\hline & & & 28 & 20.31 & 2.996 \\
\hline \multirow{3}{*}{ A 6} & \multirow{3}{*}{8} & \multirow{3}{*}{8.22} & 7 & 15.52 & 2.042 \\
\hline & & & 14 & 21.07 & 2.931 \\
\hline & & & 28 & 24.37 & 3.568 \\
\hline \multirow{3}{*}{ A 7} & \multirow{3}{*}{21} & \multirow{3}{*}{6.59} & 7 & 14.05 & 1.824 \\
\hline & & & 14 & 16.42 & 2.300 \\
\hline & & & 28 & 20.07 & 2.977 \\
\hline \multirow{3}{*}{ A 8} & \multirow{3}{*}{14} & \multirow{3}{*}{8.27} & 7 & 15.78 & 2.041 \\
\hline & & & 14 & 21.31 & 2.816 \\
\hline & & & 28 & 24.25 & 3.561 \\
\hline
\end{tabular}


Sin embargo, el presente estudio nos permite caracterizar y definir las propiedades del hormigón elaborado con áridos reciclados, remarcando que sólo se utilizó la fracción gruesa del árido reciclado y que provenía de hormigón limpio y libre de óxidos u otro tipo de material de construcción. Según los resultados, si es posible utilizar este nuevo hormigón por lo menos como hormigón en masa, según las normativas correspondientes.

\section{AGRADECIMIENTOS}

El presente trabajo estuvo auspiciado por una beca otorgada a través de la Universidad Autónoma de Tamaulipas por el Programa de Mejoramiento del Profesorado (PROMEP), según convenio Núm. UATAM-206.
Nonetheless, the properties of the concrete made with recycled aggregate could be characterized and defined in the present study, in which this aggregate was used in the coarse fraction only and the source was clean, oxidefree concrete, containing no other construction materials. According to the results obtained, at the very least this new concrete meets bulk concrete specifications.

\section{ACKNOWLEDGEMENTS}

The present research benefited from a grant awarded by the Teaching Staff Advancement Programme (PROMEP), through the Autonomous University of Tamaulipas, under agreement No. UATAM-206.

\section{BIBLIOGRAFÍA / BIBLIOGRAPHY}

(1) RILEM: "Demolición y reciclaje del concreto y la mampostería. Especificaciones para concreto con agregados reciclados", Revista IMCYC, vol. 10, no 121 (1998).

(2) Mehta, P. K.: "Advancements in concrete technology", Concrete International, vol. 96 no 4 (1999), pp. 69-76.

(3) Grupo Español del Hormigón (GEHO): Estructuras y edificación: demolición y reutilización de estructuras de hormigón, Colegio de Ingenieros de Caminos, Canales y Puertos, Madrid, 1997.

(4) RILEM: "RILEM Recomendation 121- DRG Guidance for Demolition and reuse of Concrete and Masonry. Specifications for Concrete with Recycle Aggregates", Materials and Structures, no 27 (1994), pp. 557-559.

(5) Huete, F. y Llatas, C.: "Residuos de Construcción y demolición. Propuestas para su reducción". ETSAM, VII Jornada (2003).

(6) Natalini, M. y Klees, D. Tirner, J.: Reciclaje y reutilización de materiales residuales de construcción y demolición, Comunicaciones Científicas y Tecnológicas, Universidad Nacional del Nordeste. Departamento de Estabilidad - Facultad de Ingeniería - UNNE Argentina, 2000.

(7) Parra, J. L.; Castilla, J.; Palacios, P. y Puchol, L.: "Áridos reciclados para hormigón. Prueba industrial", Jornadas Nacionales sobre aplicaciones arquitectónicas de materiales. ETS de Arquitectura, Madrid, 2003.

(8) Gómez, J. M.; Agullo, L. y Vázquez, E.: "Cualidades físicas y mecánicas de los agregados reciclados de concreto", Construcción y Tecnología del IMCYC, vol. 15, no 167 (1999), pp. 10-22.

(9) Asociación Española de Normalización y Certificación. AENOR: Hormigón estructural. Normas UNE, Madrid, España, 1999.

(10) American Society of Test and Materials. ASTM-C 143: Testing small clear specimens of timber, USA. 